Vol. 1, No. 1, Juli 2017, 86-96

Available Online at https://ejournal.warmadewa.ac.id/index.php/kulturistik

DOI: http://dx.doi.org/10.22225/kulturistik.1.1.220

\title{
NOMINALISASI BAHASA BALI
}

\author{
I Wayan Saryana \\ Warmadewa University \\ saryanaiwayan@gmail.com
}

\begin{abstract}
ABSTRAK
Penelitian ini membahas tentang masalah pokok, yaitu proses pembentukan nomina (nominalisasi) dalam bahasa Bali (BB) dan struktur nomina dalam BB. Data yang dianalisis diproleh dari intuisi peneliti, yaitu data yang digali dari potensi kebahasaan peneliti selaku penutur BB. Di samping itu, data yang dianalisis juga diperoleh dari naskahnaskah berbahasa Bali seperti novel, cerpen,dan cerita rakyat (satua). Teori yang dipakai acuan untuk menganasis data adalah teori X-bar yang dikembangkan oleh N. Chomsky dan pengikutnya mulai dari awal tahun 1970-an. Esensi penting dari teori ini adalah bahwa setiap struktur mempunyai init. Dengan kata lain, setiap struktur frasa bersifat endosentrik. Teori ini pada awalnya dikembangkan untuk menerangkan kategori frasa. Kemudian diterapkan untuk level klausa. Akhir-akhir ini diterapkan untuk menganalisis level kata (Xo). Nomina dalam BB dapat berupa nomina dasar dan nomina turunan. Nomina turunan dapat terbentuk dari beberapa proses, yaitu afiksasi, pemajemukan, perulangan ,dan turunan dari klausa. Nomina dalam BB dapat menduduki fungsi sintaksis seperti subjek, predikat, objek, pelengkap, dan keterangan.
\end{abstract}

Kata Kunci: nominalisasi, bahasa Bali

\begin{abstract}
[Title: Nominalization in Balinese Language] The study deal with the process of nominal formation (nominalization) and Nominal structure of Balinese language. The data being analyzed is obtained from the researcher's intuition that is the gained from language potency of the researcher as a native Balinese speaker. In addition, the data was also gained from Balinese texts such as novels, short stories, and folk tales. As a reference in analyzing the data it is applied X-bar theory developed by N, Chomsky and his adherers from the beginning of 1970-s. The most important essence of this theory is that every phrase structure has head. In other words, that every phrase structure is endocentric in nature. At the initial phrase, this theory was developed to describe phrasal category, then it was applied for clausal level. Recently, this theory is applied to analyze word level (Xo). Nouns in Balinese can be base and derived nouns. Derived nouns can be formed through some process: affixation, compounding, reduplication, and derivation of clauses. Nouns in Balinese can place syntactical functions such as subject, predicate, object, complement, and adverb.
\end{abstract}

Keywords: nominalization, Balinese language

\section{PENDAHULUAN}

Bahasa Bali (BB) sebagai salah satu bahasa daerah di Indonesia cukup diminati oleh para ahli untuk dijadikan objek penelitian. Baik peneliti local maupun peneliti asing sudah banyak mengangkat bahasa Bali sebagai kajian. Hal ini tampak dari hasil panalitian yang ada. Sepanjang pengetahuan penulis, hasil-hasil penelitian $\mathrm{BB}$ sudah ada yang membahas masalah nominalisasi BB, tetapi tidak 
secara khusus. Pembahasan nominalisasi BB yang telah dilakukan oleh para ahli dikemukakan dalam tinjauan pustaka.

Penelitian masalah nominalisasi BB dengan berbagai aspeknya perlu diteliti secara khusus mengingat BB seperti halnya bahasa-bahasa lain di Indonesia, merupakan bagian dari kebudayaan Indonesia yang hidup. Karena itu BB patut dibina dan dikembangkan demi kemajuan kebudayaan, khususnya BB itu sendiri.

Salah satu cara untuk melakukan pembinaan tentang BB adalah dengan mengadakan penelitian yang tujuannya antara lain adalah menggali aspek-aspek atau potensi yang dapat dipergunakan sebagai bahan pertimbangan untuk pembinaan BB. Dalam kaitan ini penulis mengangkat masalah nominalisasi BB sebagai bahan kajian. Masalah nominalisasi merupakan topic yang menarik untuk diteliti karena masalah nomina sebagai salah satu kategori menduduki posisi penting dalam system bahasa. Dikatakan penting karena masalah nomina ini dianggap sebagai salah satu kelas kata pokok di samping verba. Hal ini tercermin dalam pembagian kelas kata pada zaman Aristoteles. Pembahasan masalah nomina ini mencoba menerapkan teori X-bar. Keunikan dari teori ini bahwa setiap frasa dinyatakan mempunyai inti (head). Dengan kata lain, setiap struktur frasa bersifat endosentris.

Seperti telah dinyatakan di atas, bahwa tulisan ini membahas nominalisasi dalam BB sebagai pokok pembahasan. Ada beberapa permasalahan nominalisasi yang bisa dibahas dalam BB. Beberapa dari masalah itu meliputi :

1. Bentuk nomina dalam BB;

2. Fungsi sintaksis nomina BB dalam struktur kalimat;

3. Fungsi semantis nomina dalam kalimat BB;

4. Proses pembentukan nomina (nominalisasi) dalam BB.

Dari beberapa permasalahan tersebut di atas dibahas hanya dua masalah pokok, yaitu masalah proses pembentukan nomina BB dan masalah struktur nomina BB meliputi fungsi sintaksis nomina BB dalam struktur kalimat.

\section{METODE}

Untuk menghasilkan kajian yang akurat dari suatu penelitian ilmiah diperlukan suatu metode penelitian. Adapun metode dan teknik yang digunakan dalam penelitian ini adalah metode yang dikemukakan oleh Sudaryanto (Sudaryanto, 1986) yaitu : (a) metode dan teknik penyediaan data, (b) metode dana teknik analisis data, dan (c) metode dan teknik penyajian hasil penelitian. Ketiga tahapan itu diuraikan di bawah ini satu per satu sebagai berikut. Metode dan teknik penyajian data. Untuk memperoleh data dalam penelitian ini digunakan metode "Simak" ataau, (Sudaryanto, 1993:133). metode "Simak" ataau Observasi ini diterapkan melalui penyajian terhadap Observasi pemakaian bahasa yang diteliti (bahasa Bali). Metode dan teknik analisis data sangat menentukan hasil kajian. Menganalisis data merupakan pekerjaan puncak dari suatu penelitian, berhasil melakukan. Keberhasilan menerapkan metode dan teknik analisis data akan menghasilkan sajianpenelitian yang baik dan dapat dipertanggungjawabkan. Oleh karena itu, peneliti berusaha memilih metode dan teknik analisis data. Untuk penelitian ini, peneliti memilih metode "agih" dengan seperangkat teknik yakni unsur-unsur kebahasaan yaitu nominalisasi bahasa Bali. Analisis ini tergolong analisis kualitatif. Metode yang digunakan dalam penyajian hasil penelitian adalah metode informal dan metode formal. Metode informal yaitu penyajian yang berupapemerian atau pendeskripsian kaidah-kaidah yang 
ditemukan. Sedangkan yang dimaksud dengan metode formal ialah perumusan kaidah-kaidah dengan sistem simbol-simbol tertentu; misalnya penggunaan tanda tambah $(+)$, penggunaan garis miring $(/)$, kurung kurawal $(\{\ldots . .\}$.$) , dan sebaginya.$

\section{PEMBAHASAN}

Masalah nominalisasi dalam BB yang dideskripsikan dalam pembahasan ini, terlebih dahulu perlu pula diuraikan secara singkat beberapa pendapat mengenai pembagian kelas kata. Hal ini perlu dikemukakan karena kelas nomina yang dijadikan sasaran penelitian ini merupakan salah satu kelas kata yang ada dalam BB. Dengan mengetahui beberapa pembagian kelas kata yang dilakukan oleh para ahli, maka dapat diketahui keberadaan nomina itu sendiri dalam sistem kelas kata suatu bahasa, dalam hal ini dalam BB. Sistem kelas kata tampaknya menempati posisi yang sangat penting dalam ilmu bahasa. Dikatakan begitu karena sejak ilmu bahasa itu dikembangkan orang, sistem kelas kata sudah disinggung. Pembahasan kelas kata dikenal sejak zaman Aristoteles (abad ke-4 SM) (Kridalaksana, 1982:1).

Sistem kelas kata tampaknya menempati posisi yang sangat penting dalam ilmu bahasa. Dikatakan begitu karena sejak ilmu bahasa itu dikembangkan orang, sistem kelas kata sudah disinggung. Pembagian kelas kata dikenal sejak zaman Aristoteles, beliau membedakan dua kelas kata, yaitu onoma dan rhema. Kemudian dasar pemikiran Aristoteles itu diwarisi dan dikembangkan dalam sistem gramatika Eropa. Donatus $(350 \mathrm{M})$ misalnya, membedakan kelas kata menjadi delapan kelas, yaitu nomen, pronomen, verbum, participium, adverbium, praepositio, coniuntio, dan interiectio. Selanjutnya Priscianus $(512-560 \mathrm{M})$ membedakan kelas kata menjadi enam kelas, yaitu nomen, adiective, verbum, adverbium, praepositio, dan coniunctio (Kridalaksana, 1982: 1-5).

Pembagian sistem kelas kata bahasa Indonesia juga mewarisi tradisi Eropa yang dibawa oleh para ahli dari Eropa, seperti Spencer, Andrew (1991), dan J. Roman (1653) yang membagi kelas kata bahasa Indonesia (Melayu) menjadi tujuh kelas, yaitu nomen,voornamen, woorden, vijwoorden, voorzettingenj, koppelingen, dan inwurpen (Kridalaksana, 1982:10).

Semua pembagian kelas kata yang dilakukan para ahli menganggap nomina sebagai kelas kata tersendiri. Ini berarti keberadaan nomina sangat penting dalam sistem kelas kata suatu bahasa. Bahkan, nomina dan verba boleh dikatakan sebagai kelas kata paling dasar, sesuai dengan pembagian Plato dan Aristoteles, yaitu onoma (nomina) dan rhema (verba). Dua konsep tersebut, onoma (nomina) dan rhema itu kemudian dikembangkan lagi menjadi beberapa kelas kata (Kridalaksana, 1982:3). BB mempunyai sejumlah kelas kata. Satu di antaranya disebut nomina. Nomina ini dapat dibedakan dengan kelas kata lainnya berdasarkan bentuk, fungsi sintaksis, dan peran semantisnya. Berikut ini dikemukakan secara singkat ciri-ciri morfologis, ciri fungsi sintaksis, maupun ciri -ciri semantisnya. Dalam uraian selanjutnya akan dipaparkan fungsi nomina dan struktur klausa BB.

Teori yang diterapkan dalam tulisan ini adalah teori struktural. Teori struktural mula-mula dikembangkan oleh Ferdinand de Saussure (1916) dalam bukunya yang berjudul Course de Linguistique Generale. Teori structural beranggapan bahwa bahasa itu terdiri atas perangkat-perangkat dari tata tingkat yang paling kecil yaitu fonem sampai tata tingkat yang paling besar, yaitu kalimat yang tersusun dalam wacana. Tiap-tiap tingkat satuan bahasa mempunyai system 
Vol. 1, No. 1, Juli 2017, 89

Available Online at https://ejournal.warmadewa.ac.id/index.php/kulturistik DOI: http://dx.doi.org/10.22225/kulturistik.1.1.220

tersendiri yang berkaitan dengan system perangkat dalam tata tingkat yang lebih tinggi. Hubungan yang saling berkaitan tersebut disebut dengan struktur bahasa (Parera, 1994: 36-37).

Bahasa Bali (BB) mempunyai sejumlah kelas kata. Satu diantaranya disebut nomina. Nomina ini dapat dibedakan dengan kelas kata lainnya berdasarkan bentuk,fungsi sintaksis, dan peran semantisnya. Berikut ini dikemukakan secara singkat cirri-ciri nomina BB, baik ciri-ciri morfologis, cirri fungsi sintaksisnya. Dalam uraian selanjutnya dipaparkan fungsi nomina dan struktur klausa BB.

Bentuk-bentuk nomina dalam BB secara garis besarnya dapat dibedakan atas dua macam, yaitu nomina dasar dan nomina turunan. Nomina dasar adalah bentuk nomina yang berasal dari bentuk dasar misalnya base 'sirih', baas 'beras', meja 'meja', dan umah 'rumah'; sedangkan nomina turunan adalah bentuk nomina yang terjadi melalui proses gramatikal misalnya pengorengan "wajan", kikihan "pemarut kelapa", penyemuhan "tempat jemuran".

\section{Ciri-ciri Nomina dari Segi Bentuk}

Berdasarkan bentuknya, nomina dalam BB dapat berupa (a) nomina dasar dan nomina turunan. Kedua bentuk nomina itu dikemukakan berikut ini.

1. Nomina Dasar

Nomina dasar adalah nomina yang terdiri atas satu morfem, misalnya meja 'meja', tungked 'tongkat', yeh 'air', kedis 'burung',

2. Nomina Turunan

Nomina turunan yaitu nomina yang dibentuk melalui peristiwa gramatikal seperti afiksasi, perulangan (repetisi), atau pemajemukan (compositom), penggabungan kata menjadi frasa nomina, dan nomina yang diturunkan dari klausa.

Pertama,nomina turunan dalam BB yang dibentuk dengan cara sfiksasi meliputi kata-kata yang mengandung morfem terikat $\{p e n-\},\{p a-\},\{p i-\}$, $\{$ pari-\}, $\{$ maka- $\},\{$ peN...-an $\}$, dan $\{-a n\}$ seperti pada kata-kata berikut.

1) peN + angon $\rightarrow$ pengangon "pengembala"

2) pi- + taken $\rightarrow$ pitaken "pertanyaan"

3) pra- + cirri $\rightarrow$ praciri "tanda"

4) pa- + gelah $\rightarrow$ pagelah "kepunyaan"

5) maka- + desa $\rightarrow$ makadesa "seluruh desa"

6) pari- + solah $\rightarrow$ parisolah "hal tingkah laku"

7) kikih $+-a n \rightarrow$ kikihan "alat untuk memarut"

8) peN- + -an + goring $\rightarrow$ pengorengan "wajan"

Kedua, nomina turunan yang dibentut dengan proses perulangan (repetisi) antara lain seperti berikut. Mole-mole "perhiasan", kupu-kupu "kupu-kupu", kunang-kunang "kunang-kunang", aling-aling "tembok penghalang", bajangbajang "sejenis rumput", adeg-adeg "tiang/pilar". Ketiga, nomina turunan yang dibentuk melalui proses pemajemukan antara lain biu kayu 'pisang kayu', jebug arum 'lada', gelung kori 'pintu gerbang', briuk siu 'kompak', peteng dedet 'gelap gulita'. Keempat, nomina yang diturunkan dari penggabungan kata menjadi frasa nomina seperti umah tabuan 'sarang tawon', baju putih 'baju putih', sampi dasa 'sapi sepuluh', juru abas 'tukang babat'. 
Vol. 1, No. 1, Juli 2017, 90

Available Online at https://ejournal.warmadewa.ac.id/index.php/kulturistik DOI: http://dx.doi.org/10.22225/kulturistik.1.1.220

\section{Ciri-ciri Nomina dari Segi Fungsi Sintaksis}

Menganalisis struktur sintaksis dapat melalui tiga tataran, yaitu tataran fungsi, tataran kategori, dan tataran peran (Verhaar, 1984). Menurut Verhaar, tataran fungsi sintaksis yang meliputi: subjek, predikat, objek, pelengkap, dan keterangan dikatakannya sebagai tempat kosong yang harus diisi oleh kategori (kelas kata) sebagai pengisi bentuk dan peran semantic sebagai pengisi makna. Segi sintaksis nomina BB memiliki cirri-ciri sebagai berikut.

1. Dalam kalimat yang predikatnya berupa verba, nomina cendrung menduduki fungsi subjek, objek, atau pelengkap. Misalnya kata baju 'baju' dalam kalimat (1) adalah nomina yang menduduki fungsi subjek.

1) Bajune jemaka baan I meme (Anonim, 1996).

'bajunya diambil oleh ibu'

Demikian pula pronominal tiang 'saya' dalam kalimat (2) tergolong nomina yang berfungsi sebagai subjek.

2) Tiang meli buku (Anonim, 1996).

'Saya membeli buku'

Kata buku 'buku' dalam kalimat (2) juga tergolong nomina dan menduduki fungsi objek. Selanjutnya kata nasi 'nasi' dalam kalimat (3) merupakan nomina dan berfungsi sebagai pelengkap.

3) Tiang medagang nasi. (Anonim, 1996).

'Saya berdagang nasi'

2. Dalam struktur frasa, nomina dapat diikuti oleh ajektif, baik secara langsung maupun diselingi bentuk ane 'yang'. Misalnya kata buku 'buku' dan umah 'rumah'tergolong nomina karena bisa diperluas dengan ajektif tebel 'tebal' sehingga menjadi buku tebel 'buku tebal' dan gede 'besar' sehingga menjadi umah gede 'rumah besar' . Atau diselingi bentuk ane 'yang' sehingga menjadi buku ane tebel 'buku yang tebal', umah ane gede rumah yang besar'. Dalam struktur frasa, nomina cendrung sebagai poros atau inti frasa. Dalam hal ini, nomina menduduki bagian utama denganpewatas berada di depan atau di belakangnya. Pewatas dari frasa nomina selain berupa ajektif seperti tebel 'tebal' dan gede 'besar' tersebut di atas, bias pula berupa numeralia, verba, atau kata tugas. Ini terlihat pada contoh berikut, telung lempir 'tiga lempir', keluarga berencana 'keluarga berencana', dong murid 'bukan murid', buku ento 'buku itu'.

Unsur-unsur sintaksis dibagi menjadi tiga tataran, yaitu tataran fungsi, tataran kategori, dan tataran peran (Verhaar, 1984: 70-79). Istilah nomina termasuk dalam tataran kategori yang mengisi struktur sintaksis dari segi bentuk atau kelas kata, yang sejajar dengan verba, ajektif,numeralia, dan sebagainya; sedangkan istilah fungsi sintaksis seperti subjek, predikat, objek, keterangan, disebut sebagai "tempat kosong" yang diisi oleh kategori dan peran. Peran sintaksis ini merupakan pengisi struktur sintaksis dari segi makna seperti pelaku, sasaran, pasif,aktif, benefaktif, dan lain-lain.

Nomina dalam BB dapat menduduki beberapa macam fungsi sintaksis, seperti subjek, predikat, objek, dan pelengkap. Keempat macam fungsi yang dapat diduduki oleh nomina itu akan dikemukakan berikut ini.

1. Nomina sebagai subjek

Pada umumnya kategori nomina bahasa-bahasa di dunia dapat menduduki fungsi subjek dalam struktur sintaksis. Demikian pula halnya dalam BB, fungsi 
Vol. 1, No. 1, Juli 2017, 91

Available Online at https://ejournal.warmadewa.ac.id/index.php/kulturistik DOI: http://dx.doi.org/10.22225/kulturistik.1.1.220

subjek dala struktur sintaksis BB sebagian besar diisi oleh kategori nomina. Baik nomina dasar maupun nomina hasil dari proses gramatikal dapat menduduki fungsi subjek. Hal ini terlihat pada kalimat-kalimat berikut.

3) a. Montor nabrak cicing

'Motor menabrak anjing'

b. Kikihan aji duin bandil.

'Pemarut kelapa dari duri rotan'

c. Montor ane nabrak cicing ibusan ulung ka tukade.

'Motor yang menabrak anjing tadi jatuh ke sungai'

d. Pengorengan selem bakat gabag.

'Wajan hitam (tanpa sengaja) diraba'

Konstituen montor 'motor (4a), kikihan 'pemarut kelapa' (4b), montor ane nabrak cicing ibusan motor yang menabrak anjing tadi (4c), dan pengorengan selem 'wajan hitam' (4d) menduduki fungsi subjek dalam kalimat-kalimat di atas.

Konstituen montor 'motor' merupakan nomina dasar, sedangkan kikihan 'pemarut kelapa' merupakan bentuk nomina yang dibentuk melalui nominalisasi verba kikih 'parut' dengan afiks (sufiks) - an. Konstituen pengorengan selem merupakan frasa nomina yang berupa gabungan kata pengorengan 'wajan' dan selem 'hitam'. Selanjutnya, konstituen montor ane nabrak cicing ibusan merupakan frasa nomina yang terjadi dari proses penurunan klausa, yaitu dari klausa (kalimat) (4a) di atas.

2. Nomina sebagai predikat

Kalimat yang predikatnya berkategori nomina disebut dengan kalimat nominal. Dalam BB kata atau frasa yang berkategori nomina juga dapat menduduki fungsi predikat. Hal ini terlihat pada kalimat-kalimat beriokut.

5) a. Bapak tiange guru $S D$.

'Bapak saya guru SD'

b. Men Rai dagang canang.

'Ibunya Rai pedagang canang'

c. Made Sari adin tiange.

'Made Sari adik saya'

d. I Made pengangon sampi.

'I Made pengembala sapi'

Bentuk-bentuk guru SD 'guru SD' (5a), dagang canang 'pedagang canang' (5b), adin tiange 'adik saya' (5c), dan pengangon sampi 'pengembala sapi' (5d) berfungsi sebagai predikat dalam kalimat-kalimat di atas. Semua bentuk tersebut berkategori sebagai nomina.

3. Nomina sebagai objek

Hampir pada semua bahasa, fungsi objek hanya dapat diisi oleh kategori nomina. Demikian pula dalam BB, fungsi objek hanya dapat diisi oleh kata atau frasayang berkategori nomina.

6) a. I Meme meli nasi.

'Ibu membeli nasi'

b. Pekakne memula jagung.

'Kakeknya menanam jagung' 
c. Putu Sari meli baju anyar.

'Putu Sari membeli baju baru'

d. Wayan Dangin ngubuh kedis titiran.

'Wayan Dangin memelihara burung perkutut'

Kata nasi 'nasi' (6a) jagung 'jagung' (6b), serta frasa baju anyar 'baju baru' (6c) dan kedis titiran 'burung perkutut' (6d) menduduki fungsi objek dan keempat bentuk itu tergolong kategori nomina.

\section{Nomina sebagi pelengkap}

Kategori nomina dalam BB dapat pula berfungsi sebagai pelengkap dalam struktur kalimat. Misalnya kata kamen 'kain' (7c), kaos oblong 'kaos oblong' (7b) ,janger 'janger' (7c), dan genteng 'genteng' (7d) berkategori nomina dan semuanya menduduki fungsi pelengkap dalam kalimat-kalimat tersebut.

7) a. Luh Surati madagang kamen. 'Luh Surati berjualan kain'

b. Ia mabaju kaos oblong. 'Ia berbaju kaos oblong'

c. Putu Sari ngigel janger 'Putu Sari menari janger'

d. Umahne maraab genteng.

'Rumahnya beratap genteng'.

5. Nomina berperan hasil.

Nomina berperan sebagi hasil pada umumnya berupa nomina

\section{Ciri-ciri Nomina dari Perilaku Semantis}

Segi semantis nomina adalah kata yang mengacu pada manusia, binatang, benda, dan konsep atau pengertian. Kata seperti guru 'guru' meong 'kucing, bagus 'ganteng' adalah nomina (Sulaga, I Nyoman, 1996: 223). Lebih lanjut dijelaskan bahwa tiap-tiap kata dalam bahasa mana pun mengandung fitur-fitur semantik yang secara universal melekat pada kata-kata tersebut. Demikian pula dengan nomina sudah tentu memiliki fitur-fitur yang berlaku universal. Misalnya apa yang disebut jaran 'kuda' dalam BB akan memiliki fitur-fitur semantik yang sama dalam budaya mana pun atau bersifat universal. Fitur-fitur semantik yang dimiliki oleh konsep jaran 'kuda' itu antara lain: binatang berkaki empat, bermata dua, warna bulunya bisa hitam, putih, coklat, abu-abu, atau mungkin loreng. Fitur -fitur semantik sepeti itu sangat penting dalam bahasa. Jika terjadi penyimpangan akan menimbulkan kejanggalan. Misalnya karena warna jaran 'kuda'itu hanya bisa hitam, putih, coklat, abu-abu, atau mungkin loreng, kalimat berikut.

8) Jaran tiange gadang

'Kuda saya hijau'.

Kejanggalan itu terjadi karena fitur semantis gadang 'hijau' pada kuda tidak ada. Fitur semantis jaran 'kuda' juga mencakup beberapa kegiatan seperti: ngamah 'makan, pules 'tidur', melaib 'berlari'. Akan tetapi fitur-fitur yang berupa kegiatan seperti 'memaca 'membaca', ngaroko 'merokok', mabakti 'sembahyang' terasa sangat ganjil jika diterapkan untuk jaran 'kuda' karena binatang itu tidak bisa melakukan kegiatan seperti itu. Karena itu, kegiatan- 
kegiatan seperti memaca 'membaca', ngaroko 'merokok', dan mabakti 'sembahyang' tidak cocok untuk mendeskripsikan .fitur-fitur semantis jaran 'kuda'. Dengan demikian, setiap kata, termasuk nomina, memiliki fitur-fitur semantis yang universal. Fitur-fitur semantis itu selalu melekat pada kata-kata tersebut.

Ditinjau dari perilakunya dalam struktur sintaksis, peran semantis nomina BB dapat dilihat dari susunan fungsi sintaksisnya. Seperti sudah disebutkan di atas bahwa peran semantis merupakan pengisi fungsi sintaksis dari segi makna, pengisi fungsi sintaksis dari segi bentuk adalah katagori atau kelas kata. Nomina merupakan salah satu kelas kata yang dapat mengisi fungsi-fungsi sintaksis itu.

Nomina yang dapat mengisi fungsi sintaksis itu jika dilihat dari segi peran semantisnya ada beberapa macam peran, misalnya peran pelaku, sasaran, penerima, alat, hasil, pengalam, tempat, sebab, dan lain-lain (Sulaga, I Nyoman, 1996: 374-376). Berikut ini dikemukakan peran semantis nomina itu seperti dalam kalimat-kalimat berikut.

1. Nomina berperan pelaku.

Peran pelaku adalah partisipan yang melakukan perbuatan yang pada umumnya berupa nomina insan. Ini terlihat pada kalimat-kalimat berikut.

9) a. Cicing nguber meong.

'Anjing mengejar kucing'

b. Gegendonge ento nagih ngidih nasi.

'Pengemis itu mau minta nasi'

Nomina . Cicing 'anjng' pada kalimat (9a) dan nomina gegendonge ento 'Pengemis itu' pada kalimat (9b) menduduki fungsi subjek. Kedua nomina tersebut berperan sebagai pelaku.

2. Nomina berperan sasaran

Nomina yang berperan sebagai sasaran dapat brupa nomina insan dan nomina bukan insan. Ini terlihat pada kalimat-kalimat berikut.

10) a. I Kobar ngematiang Gede Dibya.

'I Kobar membunuh Gede Dibya'

b. Pan Madu negul sampine.

'Ayahnya Madu mengikat sapinya'

c. Bapane ngempug saang.

'Ayahnya membelah kayu bakar'

Nomina Gede Dibya 'Gede Dibya' pada kalimat(10a), sampine 'sapinya' pada kalimat (10b), dan saang 'kayu bakar' (10c) menduduki fungsi objek. Ketiga nomina tersebut berperan sasaran.

3. Nomina berperan penerima.

Nomina berperan penerima pada umumnya berupa nmina insan seperti yang terlihat pada kalimat-kalimat berikut.

11) a. Ni Sari maan surat uli Belanda.

'Ni Sari mendapat surat dari Belanda'

b. Ni Sari meliang adinne baju.

'Ni Sari membelikan adiknya baju' 
c. Meme ngemang kucit ngamah.

'Ibu memberikan babi makan'

Nomina Ni Sari Ni Sari' dalam kalimat (11a) menduduki fungsi subjek, sedangkan nomina adinne 'adiknya' dalam kalimat (11b) dan nomina kucit 'babi' pada kalimat (11c) menduduki fungsi objek. Ketiga nomina tersebut berperan sebagai penerima.

4. Nomina berperan alat.

Nomina berperan alat pada umumnya berupa nomina tak bernyawa. Nomina ini merupakan alat atau sarana untuk melakukan kegiatan seperti yang dinyatakan dalam verba predikat. Hal ini terlihat pada kalimat-kalimat berikut.

12) a. Batu anggone nimpug tiang.

'Batu diakai melempar saya'

b. I Belong nugel tiing aji regaji.

'I Belong memotong bambu dengan gergaji'

Nomina batu 'batu' pada kalimat (12a) menduduki fungsi subjektak bernyawa. Ini terlihat pada kalimat-kalimat berikut.

13) a. Togoge ento pakardin pekak tiange.

'Patung itu buatan kakek saya'

b. Suba liu tiang mragatang gambaran.

'Sudah banyak saya merampungkan lukisan'

Nomina togoge ento 'patung itu' pada kalimat (13a) menduduki fungsi subjek, sedankan nomina gambaran 'lukisan' pada kalimat (13b) menduduki fungsi objek. Kedua nomina tersebut berperan sebagai hasil.

5. Nomina berperan pengalaman.

Nomina berperan pengalaman adalah partisipan yang mengalami keadaan atau peristiwa seperti yang dinyatakan dalam predikat. Peran pengalam ini biasanya berkedudukan sebagai subjek dari kalimat yang berpredikat ajektif atau verba intransitif (Sulaga, dkk, (penyunting), 1996: 374). Ini terlihat pada kalimatkalimat berikut.

14) a. Adinne sakit.

'Adiknya sakit'

b. Memenne ngeling.

'Ibunya menangis'

Nomina adinne 'adiknya' pada kalimat (14a) dan nomina memenne 'ibunya' pada kalimat (14b) menduduki fungsi subjek. Kedua nomina tersebut berperan pengalam atau mengalami peristiwa seperti yang dinyatakan oleh predikat.

6. Nomina berperan tempat.

Nomina berperan tempat pada umumnya berupa nomina tak bernyawa. Ini terlihat pada kalimat-kalimat berikut.

15) a. Tiang tusing bani mangunan umah di karange ento.

'Saya tidak berani membangun rumah di pekarangan itu' 


\section{b. Hotele ento liu misi tamu.}

'Hotel itu banyak tamunya'

Nomina karange ento 'pekarangan itu' (bersama-sama preposisi $d i$ 'di' ) pada kalimat (15a) menduduki fungsi keterangan, sedangkan nomina hotele ento 'hotel itu' pada pada kalimat (15b) menduduki fungsi subjek. Kedua nomina tersebut berperan sebagai tempat.

7. Nomina berperan sebab.

Nomina berperan sebab pada umumnya berupa nomina tak bernyawa. Nomina berperan sebab ini merupakan penyebab suatu peristiwa seperti yang dinyatakan dalam predikat. . Ini terlihat pada kalimat-kalimat berikut.

16) a. Angine ngeberan don-donan.

'Angin itu menerbangkan dedaunan'

b. Apine muunang umah

'Api itu membakarrumah'

Nomina angine 'angin itu' pada kalimat (16a) dan nomina apine 'api itu' pada kalimat (16b) menduduki fungsi subjek. Kedua nomina tersebut berperan sebab, yaitu penyebab terjadinya suatu peristiwa.

\section{SIMPULAN}

Berdasarkan uraian yang dikemukakan dalam Bab-bab sebelumnya dapat disusun beberapa simpulan. Ditinjau dari satuan kebahasaan pembentu nomina $\mathrm{BB}$, maka nomina dalam BB ada dua jenis, yaitu nomina dasar dan nomina turunan. Nomina dasar adalah nomina yang terjadi dari bertuk leksikal yang sudah berkelas nomina sebelum mengalami proses morfologis. Nomina turunan adalah nomina yang terbentuk sesudah suatu satuan kebahasaan mengalami proses morfologis.

Pembentukan nomina turunan dapat dilakukan melalui proses afiksasi, pemajemukan, penggabungan unsur-unsur leksikal menjadi frasa, dan penurunan klausa menjadi frasa nomina. Dalam BB ada sejumlah afiks yang dapat membentuk nomina, yaitu (1) prefiks peN-, pe-,pre-. (2) infiks -el-, (\#) sufiks $a n,-e$, (4) dan konfiks $k e--a n, p a--a n$. Nomina yang terbentuk dari proses pemajemukan dapat dilakukan melalui perpaduan satua bahasa yang berkelas: nomina + nomina, nomina + prakategorial, ajektif + ajektif, ajektif + prakategorial.

Nomina yang terbentuk dari perulangan satuan-satuan bahasa ada beberapa macam, yaitu: (1) perulangan dwipurwa yakni perulangan suku kata pertama pada leksem dengan pelemahan fonem vocal, perulangan dwilingga yakni perulangan satuan-satuan bahasa atau leksem secara utuh.

Nomina yang dibentuk berdasarkan penggabungan leksem dengan leksem lain menjadi frasa nomina. Leksem-leksem pembentuk frasa nomina itu dapat berupa gabungan dari: nomina + nomina, nomina + ajektif, nomina + numeralia, dan nomina + verba.

Nomina turunan yang dibentuk dengan penurunan klausa menjadi frasa nomina ada dua macam, yaitu nomina yang diturunkan melalui perelatifan dengan ane / sane 'yang' dan nomina yang diturunkan dari penominalan FV (frasa verba) predikat klausa serta permutasian FV yang dinominalisasi itu ke 


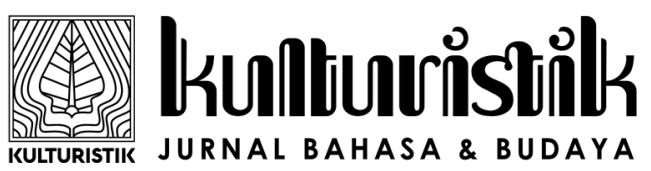

Vol. 1, No. 1, Juli 2017, 96

Available Online at https://ejournal.warmadewa.ac.id/index.php/kulturistik DOI: http://dx.doi.org/10.22225/kulturistik.1.1.220

depan. Ditinjau dari fungsi sintaksis yang dapat diduduki oleh nomina dalam struktur kalimat atau klausa, nomina dalam BB dapat berkedudukan sebagai subjek, predikat, objek, pelengkap, dan keterangan.

\section{DAFTAR PUSTAKA}

Anonim. (1996). Cerpen Basa Bali. Denpasar: Saba Sastra Bali.

Kridalaksana, H. (1982). Kamus Linguistik. Jakarta: PT. Gramedia.

Parera, J. D. (1994). Morfologi bahasa (edisi kedua). Jakarta: PT Gramedia Pustaka Utama.

Sudaryanto. (1986). Metode linguistik. Yogyakarta: Gadjah Mada University Press.

Sudaryanto. (1993). Metode dan Aneka Teknik Analisis Bahasa. Yogyakarta: Duta Wacana University Press.

Sulaga, I Nyoman, dkk. (1996). Tatanan bahasa baku bahasa Bali. Denpasar: Pemerintah Propinsi Daerah Tingkat I Bali.

Verhaar, J. W. . (1984). Pengantar linguistik. Yogyakarta: Gadjah Mada University Press. 